\title{
The Banking Fragility Index Panorama in China
}

\author{
Wang Yunyi \\ Tokyo University of Foreign Studies, Tokyo, Japan,wangyy92@outlook.com
}

\begin{abstract}
The corresponding impact on china's banking system is becoming the focus issues of international economy and has become the major theoretical and practical issues for China to deal with the increasingly complex international economic situation. Since 2004 the formation mechanism reform started, China's banking system experienced a steady development and the supervision on banking fragility keeps pace with times to meet the requirement of operation. How to measure a bank's operational performance is not get to a conclusion in academic field. This paper aims to review the measurement of banking fragility index of Western and Eastern world and using data on Chinese banks to develop an index of banking fragility and subsequently examine the factors affecting the index. Industry analysis will be introduced in this paper. The academic debates on factors affecting banking fragility index are analyzed and this paper will choose a number of widely-used index for the regression test. The findings about the effective countermeasures to the banking fragility Chinese banks facing as well as the objectives of the financial reform are discussed. A conclusion presents the resulting implications for further research.
\end{abstract}

KEYWORDS: Banking, Fragility, China, Regression

\section{Introduction}

A stable bank fragility index is important to economy growth of a country. It can also lead to a new financial policy or an unexpected bank run. Since formation mechanism reform of China's banking system in 2004, it experienced a steady development of China's banking system. Especially after the 2008 worldwide financial crisis, compared with European and American national banks, China's banking system achieved a remarkable result. Chinese banks are still facing high risks which cannot be neglected. The pressure on the non-performing loans continued to grow worldwide. Under the conditions that the country's commercial banks are weak on financial strength, inadequate on capital, not perfect on operating mechanism, unreasonable on management models and shortage on talent pool, it is significant to study China's commercial banking system's fragility, determine their trend and give rationalized and feasible countermeasures and suggestions to enhance the stability of China's banking system. The subsequently developed bank monitoring policies and the corresponding impact on china's economy are becoming the focus issues of international economy, and also has become the major theoretical and practical issues for China to deal with the increasingly complex international economic situation which must be faced up to.

First, this paper will explore China's bank fragility index based on local research and Kaminsky (1998, 26-28)'s method using the bank's data from 2007 to 2018. Second, this paper will find what indicators affect the BFI in China. Third, this paper will explore whether China should actively promote the reform of financial environment mechanism while taking the initiative, in a controllable and gradual manner. In the meantime, it will also put forward countermeasures which China may take facing different situations and recommendations on the reform of the banking system policy.

\section{China's current banking system}

With the first Japanese bank opened in Beijing in 1980, the liberalization of Chinses banking system has started. At the end of 1990s, under the huge effect of Asian financial crisis, the ratio of China's non-performing loan has dramatically increased to $30 \%-40 \%$ of total loan. (Ran Li, Xiang Li, Wen Lei and Yiping Huang, 2015,72)

Although mainland China has survived from the 1997 Asian financial crisis, but not until 2006, The China Banking Regulatory Commission (CBRC) announced its approval for nine foreign-funded banks to start their preparatory work in China. (PwC financial report, 2016, 28) Meanwhile $\mathrm{CBRC}$ is committed to comply with the following regarding the foreign bank 
restrictions cancellation, the RMB business and the foreign currency business of foreign banks: (a) all restrictions on the target customers to foreign banks in dealing foreign exchange business are supposed to be already cancelled; (b) all current unnecessary measures regarding the issuing licenses will be cancelled; (c) foreign invested financial leasing companies may, in accordance with the same conditions for Chinese financial leasing companies, provide financial leasing services. (Javier Serrado and Banco Sabadell 2003, 3)

Due to the rapidly growth of economy in China, good investment environment, there is a huge increase of foreign Banks in mainland China including their branches. Statistics show that foreign banks now account for about $1.26 \%$ of the total market share in China. These market shares are hold by 1013 foreign banks from 21 areas in the world. (The World Bank 2018, 6)

Foreign Banks are more competitive in capital strength, international network, management experience compared with Chinese commercial banks. Their significant advantages are risk management and risk control. In the wake of the Asian crisis a decade ago and even more recently, during the banking crises in Argentina and Turkey, policymakers have been making pro - active efforts to restructure their banking systems (Hoelscher and Ingves 2006, 13-15). There are following advantages of the entry of foreign banks: (a) It will improve local banks service standard. (b) It will deepen the recapitalization of the society. (c) Local banks can modify the remaining management method in order to reduce management risks. At the same time, foreign Bank's entry strengthens the competition between banks in the financial market. (Ghosh 2010, 24) It is obvious that the local banks has lack of capital, unsound management mechanism, unreasonable management mode compared with foreign banks, this will no doubt increases the overall risk of Chinese commercial Banks and increases their vulnerability, at last results in the decrease of the ability to resist risk.

On the other hand, as one of America's largest trading partner, the outbreak of the subprime crisis in the United States not only bring direct losses to China's commercial Banks which involved in foreign investment, but also brought huge influence to the export of China. The U.S. subprime mortgage crisis caused its domestic consumption sharply shrinking which directly scroll down China's export volume. Export income takes a crucial part in GDP of China. China's economy is almost an export-oriented economy; this makes a large impact on the country's macro economy. So, the U.S. subprime crisis made a negative impact on the the commercial banking system in China, to some extent, increased their vulnerability.

\section{Methodology and Main Findings}

The ratio of credit to GDP growth and the Chinese banking system fragility is significantly correlated, the inflation rate and current account/GDP ratio has weakly significant correlation with the fragility of the banking system, while the GDP growth rate, the fiscal deficit/GDP and the stock market price-earnings ratio have very low correlation with the fragility of the banking system (Han 2000, 33).

Liquidity factors are the main factors due to Ming Zheng (2003, 48-50)'s research, but its effectiveness was significantly decreased, while the effectiveness of credit risk and market risk does not decline, contrary show a rising trend since year 2005. She doesn't choose NPL ratio when constructing the model, she thinks that the source of the data does not accurately reflect the real situation of banks in China.

A non-linear (downward opening direction parabolic) relationship is found in Zhiqiang (2012, 91-94)'s paper between liquid assets and profitability and the strikingly different behaviour of liquid management of four major state-owned commercial banks and ten share-holding commercial banks. This study also found that four state-owned commercial banks and shareholding commercial banks have a completely different mobility management model, the state take responsibility of commercial banks' liquidity risk and insolvency risk and provide implicit guarantee, so the four major banks reduce liquid assets and configure more high-yield assets.

The main reasons of Asian crisis are Moral Hazard and Overinvestment suggested by Krugman (1998) as a New Keynesian economics and Ming Zheng (2003, 51-52). They believe that 
government and financial institutions have such implicit transactions and will continue to do so to make prices stable. The government takes too much responsibility for banking system. The vulnerability of China's financial system is caused by state-controlled financial system and subsidies policy within the system as Yingli $(2002,14-15)$ argued.

Nonbank institutions' excessive debt in China are blamed to lead to banking system fragility. It brings forward that bad debt is the basic reason of Asian financial crisis and a surefire borrower credit risk identification system is very necessary not only for Asian bank but also for the whole world banking system.

Other argues that information asymmetry is the main reason of China's bank fragility and this reason takes more and more important place in China. Researches point out that the degree of openness and commercial bank fragility of the banking system; foreign banks entrance and the number of crises is both negatively correlated.

Analysis on the relevant data of the commercial banks from 1991-2000 shows that noting of the vulnerability of commercial banking system are due to the following factors: inflation rate, fixed asset investment growth rate, fiscal deficits, deposit and loan spreads, import growth rate, etc. Hongbo $(2004,8)$ in his paper proposes state-owned commercial banking system fragility are affected by macroeconomic factors more than microeconomic factors; the interest rate, growth rate, inflation rate is the most important reason of bank fragility. Wei (2005, 48-56) did her empirical research of the institutional analysis variables and achieved a good regression result, confirmed the main factor of the vulnerability of China's banking system is the supporting institutional factors.

Summarized above literature, the most common factors regarding to China's bank fragility are shown in below table 1.1 .

Table 1.1 Micro and Macro Factors Regarding to China’s Bank Fragility

\begin{tabular}{|c|c|c|c|c|c|c|c|c|}
\hline \multicolumn{4}{|c|}{$\operatorname{Macro}(4)$} & \multicolumn{5}{|c|}{ Micro(5) } \\
\hline $\begin{array}{l}\text { GDP } \\
\text { growth } \\
\text { rate }\end{array}$ & $\begin{array}{l}\text { CP } \\
\text { I }\end{array}$ & $\begin{array}{l}\text { Capital } \\
\text { account } \\
\text { opennes } \\
\text { s ratio }\end{array}$ & $\begin{array}{l}\text { Changes in } \\
\text { exchange } \\
\text { rate }\end{array}$ & $\begin{array}{l}\text { Capit } \\
\text { al } \\
\text { Adeq } \\
\text { uacy } \\
\text { Ratio }\end{array}$ & $\begin{array}{l}\text { NPL } \\
\text { rati } \\
\text { o }\end{array}$ & $\begin{array}{l}\text { The } \\
\text { average } \\
\text { return on } \\
\text { net assets }\end{array}$ & $\begin{array}{l}\mathrm{RMB} \\
\text { deposit } \\
\text { ratio }\end{array}$ & $\begin{array}{l}\text { Foreign } \\
\text { currency } \\
\text { deposit } \\
\text { ratio }\end{array}$ \\
\hline
\end{tabular}

This paper follows the Xiliang Liu, Xin Zeng (2011, 25-32)'s BFI equation in his research. A comprehensive BFI equation should clearly reflect the following three factors: liquidity, stability, profitability. Deposit ratio for both RMB and foreign currency, NPL ratio and ROE ratio, these indicators take on board the three major dimensions of banking operations: stability, liquidity and profitability. (Demirguc Kunt and Huizinga, 2004, 377, 380, 390-398)

To construct the BFI, we proceed as follows. For any year i, the index for the ith dimension, BFIi, is given by the expression:

$\mathrm{BFI}_{i}=\left(\frac{R D C B_{i}-\mu r d c b}{\sigma r d c b}\right)^{2}+\left(\frac{N P L_{i}-\mu n p l}{\sigma n p l}\right)^{2}+\left(\frac{R O E_{i}-\mu r o e}{\sigma r o e}\right)^{2}$

Where RDBC represents RMB deposit ratio; $\mu$ represents the indicator's arithmetic mean; $\sigma$ represents the indicator's Standard deviation. The significance of BFI is as follows: (a) the construction of BFI makes the above four indexes behave according to chi-square distribution. Based on the bank's time series data, we can describe the variation trend of BFI of the bank which reflects the variations of the bank's fragility. (b) When the surveyors limit the Index within a given confidence interval, we can figure out the range of values of BFI. If the actual value of BFI is beyond the range, the bank is in fragile state this year. (c) If we put the critical values of the above four indexes that are regulated by supervision department into the formula, we can calculate a value 
of BFI. When the actual value of BFI is smaller than the set value, the bank is instable situation this year according to the supervision standards; when the actual value is bigger than the set value, the bank is in fragile situation this year according to the supervision standards. (d) if we have enough quantity of the samples collected from the bank, the accuracy will improve when we use the Index to estimate the level of the bank's fragility. (e) We can further expand BFI by bringing into more indexes, such as macroeconomic index. Therefore, we can use the deviation degree of the actual value of BFI from the average historical data to estimate the level of the bank's fragility and the probability of calculating the level of fragility without relying on the sample data of bank failures or crisis. It also possesses early warning function and is suitable to China. The disadvantage is that the high accuracy of BFI requires a large amount of historical data of samples collected from the bank.

The data for the analysis is drawn from "China Financial Yearbook", "China Statistical Yearbook", China Economic Information Network statistics database, China Banking Regulatory Commission Annual Report, Thomason One Banker database and World Economic Outlook by IMF and CBRC annual report.

Table 1.2 Summary statistics of the whole industry data and generated BFI of China

\begin{tabular}{|l|l|l|l|l|l|l|l|l|l|}
\hline & RDCB & NPL & ROE & BFI & & RDCB & NPL & ROE & BFI \\
\hline $\mathbf{2 0 0 7}$ & 0.7689 & 0.1175 & 0.1085 & $4.5337(1)$ & $\mathbf{2 0 1 3}$ & 0.6687 & 0.0482 & 0.1794 & $2.8098(0)$ \\
\hline $\mathbf{2 0 0 8}$ & 0.7392 & 0.1100 & 0.0928 & $3.5200(1)$ & $\mathbf{2 0 1 4}$ & 0.6772 & 0.0176 & 0.1485 & $0.6164(0)$ \\
\hline $\mathbf{2 0 0 9}$ & 0.7506 & 0.1065 & 0.1281 & $1.9360(0)$ & $\mathbf{2 0 1 5}$ & 0.6807 & 0.0126 & 0.1375 & $0.3800(0)$ \\
\hline $\mathbf{2 0 1 0}$ & 0.7045 & 0.0958 & 0.1452 & $0.0606(0)$ & $\mathbf{2 0 1 6}$ & 0.6820 & 0.0100 & 0.1160 & $0.9350(0)$ \\
\hline $\mathbf{2 0 1 1}$ & 0.6810 & 0.0750 & 0.1525 & $0.5824(0)$ & $\mathbf{2 0 1 7}$ & 0.6982 & 0.0095 & 0.1050 & $1.3419(0)$ \\
\hline $\mathbf{2 0 1 2}$ & 0.7239 & 0.0635 & 0.1713 & $1.5947(0)$ & $\mathbf{2 0 1 8}$ & 0.6539 & 0.0097 & 0.1794 & $3.7729(1)$ \\
& & & & & & & & & \\
\hline
\end{tabular}

China's commercial banking system is fragile between 2007 and 2009, which is the period of the worldwide financial crisis. In 2007, affected by the RMB inflation as well as the outbreak of American financial crisis, banks in China face higher fragility (Dwight H. Perkins, 2018, 141). From 2018, due to the intense economic relationship with US, the BFI was increasing gradually and achieved the alarming line.

The RDCB in 1993 in China is $113 \%$, it decreased to $80.3 \%$ till 2000 and drop to $60 \%-70 \%$ level. Banks have enough liquidity to offend the risks (Ran Li, Xiang Li, Wen Lei and Yiping Huan 2015, 75). Since 1999, the state council set up four financial asset management companies who will take charge of stripping off non-performing loans from financial institutions, according to CBRC 2011 annual report, as of to June 2010 total amount of stripped non-performing loans of financial institutions is 2.0389 trillion $\mathrm{RMB}$, the non-performing loans of foreign currency is up to 33.35 billion RMB. But through the test with confidence level of $95 \%$, the model shows that the NPL ratio is the primary issue that plagues China's banking fragility.

ROE is closely relative to the vulnerability of the bank, blind pursuit of profit and maximize profit exits in China's banking industry, thus management level may ignore the asset quality, resulting in the improvement of the non-performing loan ratio and increase in the vulnerability ratio of the bank. 


\section{Further statistic test on macroeconomic factors}

We already generated BFI using 3 main significant microeconomic factors. To what extend the macroeconomic factors affect the index will be discussed in this chapter. We construct LS model to test the correlation between BFI and main macroeconomic factors. The dependent variable y is the BFI described earlier. Independent variables include 4 macroeconomic variables in the basic equation: x1: GDP; x2: CPI; x3: Capital account openness ratio; $x 4$ : changes in exchange rate. We standardized $\mathrm{x} 1$ to $\mathrm{x} 4$ by equation (2) and take $\ln$ for each serious (for adjusted $\mathrm{y}=\mathrm{y}-$ minimum/maximum-minimum) gathered data are shown in below table1.3.

$$
x_{i}=\left(\frac{x_{i}-\mu x_{i}}{\sigma x_{1}}\right)^{2}
$$

Table 1.3 Draft Data for BFI Regression

\begin{tabular}{|c|c|c|c|c|}
\hline lny & $\ln x 1$ & $\ln x 2$ & $\ln x 3$ & $\ln x 4$ \\
\hline 0.693 & 0.401 & 0.483 & 0.693 & 0.040 \\
\hline 0.573 & 0.348 & 0.161 & 0.302 & 0.693 \\
\hline 0.354 & 0.271 & 0.007 & 0.058 & 0.145 \\
\hline 0.000 & 0.197 & 0.090 & 0.013 & 0.002 \\
\hline 0.110 & 0.116 & 0.123 & 0.187 & 0.185 \\
\hline 0.295 & 0.028 & 0.061 & 0.330 & 0.005 \\
\hline 0.479 & 0.000 & 0.188 & 0.099 & 0.192 \\
\hline 0.117 & 0.013 & 0.465 & 0.036 & 0.390 \\
\hline 0.069 & 0.112 & 0.001 & 0.000 & 0.000 \\
\hline 0.179 & 0.325 & 0.123 & 0.012 & 0.010 \\
\hline 0.252 & 0.497 & 0.238 & 0.006 & 0.063 \\
\hline 0.604 & 0.693 & 0.693 & 0.272 & 0.169 \\
\hline
\end{tabular}

In order to analysis to what extend the independent variables affect the BFI, we construct model:

$$
\mathrm{y}=\beta_{1}+\beta_{2} x_{1}+\beta_{3} x_{2}+\beta_{4} x_{3}+\beta_{5} x_{4}+\mu
$$

Here $\beta \_\mathrm{i}$ is coefficient and $\mu$ is random variable. Regression results in $\mathrm{R}$ :

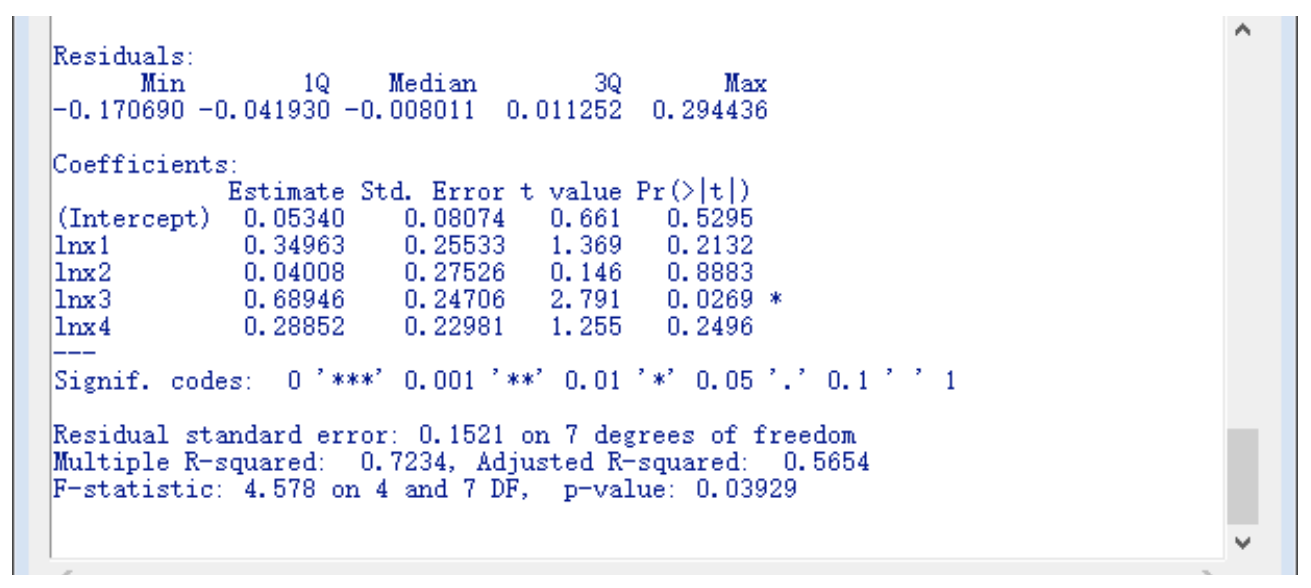

According to data in the table, the model estimated as:

$$
\mathrm{Y}=0.05+0.35 x_{1}+0.04 x_{2}+0.69 x_{3}+0.29 x_{4}+\mu
$$


The $\mathrm{p}$ value of each observation shown as below table 1.4:

Table 1.4 P Value Result

\begin{tabular}{|c|c|c|c|c|}
\hline & $\mathrm{X} 1$ & $\mathrm{X} 2$ & $\mathrm{X} 3$ & $\mathrm{X} 4$ \\
\hline P value & 0.094 & 0.078 & 0.005 & 0.307 \\
\hline
\end{tabular}

Given significance level $\mathrm{a}=0.05$, The $\mathrm{p}$ value of $\mathrm{X} 3$ is smaller than a. Hence the coefficient on capital account openness ratio is positive and statistically significant. This suggests that greater changes in capital account openness ratio leads to an improvement in banking BFI. The magnitudes indicate: a 10\% rise in changes in capital account openness ratio raises banking fragility by roughly $5 \%$. The macro indicators have no remarkable effect on the fragility index of banks, but still should not be ignored. According to the model, macro indicators failed the statistical test, it may cause by that the financial economic transition period China is in which is not yet fully market-oriented. The current bank vulnerability more rely on microcosmic body. However, we still find through the regression model that the changes of exchange rate has obvious effect on BFI, this reminds us that at the same time, with the acceleration development of China's financial and economic marketization, we need to keep a close eye on the impact of macroeconomic factors.

\section{Conclusion}

Monitoring ultimate owner of lender takes an important role in maintaining China's financial market stability and reduces the vulnerability of the banking system for the short term is necessary. Eliminate the bank depositors caused by panic can make the economy in a stable level. At the same time we must see that compared with foreign advanced control network belonging to a more extensive management pattern, China's policy of ultimate owner remediation has the shadow of old policy. No matter in what kind of risk central bank would bail out, this made commercial banks ignore risks that already exist. The Moral Hazard thereby significantly increasing instability (Weiqun 2006, 28-31). What to do reasonably for central bank is that seize the best opportunity to rescue, at the same time avoid the transition of the ultimate owner from one firm to another or typically from parent company to is subsidiaries.

As for the Long-term strategy: Strengthening bank balance sheets. The government has borrowed heavily to recapitalize banks and take NPLs off their books. In 1998, it issued $\$ 32$ billion in bonds to recapitalize the banking sector. In 1999-2000, bonds were issued by four asset management companies (one for each SCB) to absorb approximately $\$ 170$ billion of bad loans.( Xuguang and Luo 2005, 25-30) Chinese commercial banks are now adopting balance sheet criteria that reflect international practices; for example, as recommended under the 1988 Basle Accord, risk-based capital ratios of $8 \%$ are being maintained, although there is concern among some analysts that the Basle criteria understate the riskiness of assets held. Loan-loss provisions are now to reflect asset quality, and since the beginning of 2001, they are gradually reaching levels of $100 \%$ compared to $1 \%$ of loan balances previously (Zhiqiang 2012, 93). Financial statement definitions are also gradually being brought in line with international standards.

Using commercial lending criteria. According to legislation and rules adopted in the mid1990s, banks now must base lending on commercial criteria. At present, this policy is being adopted gradually throughout China. (Wei 2005, 51-54) To reduce risk exposure, loans must be made against collateral, banks must assess borrower creditworthiness, and loans to a single borrower must not exceed 10\% of bank capital (Yu Kang, Ling Ling, Meng Luo, 2012, 10-11). To shield banks from political pressure, individuals and nonbank organizations may not interfere in bank operations. Commercial banks may not give unsecured loans to related parties or provide secured loans on preferential terms. 
Improving globalization. More Chinese firms and banks are listing their shares, exposing them to market discipline. The top 100 firms listed in China's stock exchanges have some state ownership (Ran Li, Xiang Li, Wen Lei and Yiping Huan 2015, 88). The Bank of Shanghai welcomed three international shareholders, including the global banking giant Hong Kong and Shanghai Banking Corporation (HSBC) and the International Finance Corporation (IFC) under the World Bank, which hold 8 percent and 7 percent respectively of the Shanghai Bank's shares. In a recent development, an Australian bank has established a joint-venture with $\mathrm{CCB}$, the largest provider of private housing loans in the country to process mortgages (Perkins, 2018, 148-153). Banks also are required to introduce governing boards and are to be audited by an approved accounting firm.

\section{References}

Demirguc-Kunt, A., and Harry Huizinga. 2004. "Market discipline and deposit insurance." Journal of Monetary Economics 51(2): 375-399.

Detragiache and Demirguc-Kurt. 1998. "The Determinants of Banking Crises in Developing and Developed Countries" IMF Staff Papers 45(1): 3564.

Ghosh, Saibal. 2010. "Credit Growth, Bank Soundness and Financial Fragility: Evidence from Indian Banking Sector." MPRA Paper 24715, University Library of Munich, Germany, 24.

Han, Jun. 2000. Banking System Stability. China Financial Publishing House, 22-35.

Hoelscher D.S., and Ingves S. 2006. "The Resolution of Systemic Banking System Crises." Bank Restructuring and Resolution, 3-23.

Krugman, Paul. 1998. What Happened to Asia? Available at www.mit.edu./people/Krugman, 1999-12-24.

Lindgren, Garcia, Saal. 2009. "Bank Soundness and Macroeconomic Policy." IMF Working Paper No.96-18.121-165.

Minsky, Hyman. 1982. The Financial Fragility Hypothesis: Capitalist Process and the Behavior of the Economy in Financial Crises. Cambridge University Press, 23-35.

Perkins, Dwight, H. 2018. "The complex task of evaluating China's economic reforms." China's 40 Years of Reform and Development: 1978-2018 (8):135-154.

Ran, Li, Xiang Li, Wen Lei and Yiping Huan. 2015. "Consequences of China's opening to Foreign Banks.” China's Domestic Transformation in a Global Context (4):67-90.

Serrado, J., and Banco Sabadell. 2003. "China's Entry into The WTO and The Financial Sector.” Feb. 2003. Beijing, 3

Wei, Zou. 2005. "Banking System Stability in China.” Economic Science Press 2005: 23-56.

Weiqun, Li. 2006. "Empirical Research on China's Capital Account Liberalization and Banking Fragility.” Statistical Research (7): 28-31.

Xiliang, Liu, Xin Zeng. 2011. "Research on China's Financial System Vulnerability and Moral Hazard.” Finance and Trade Economics (1): 25-32.

Xuguang, Nan, Huiying Luo. 2005. "Analysis of Financial Fragility Based on Entropy Theory.” Meizhong Jingji Pinglun 5(3):29-32.

Yu, Kang, Ling Ling, Meng Luo. 2012. “Chinese Banking System Fragility of Empirical Research Based on VAR Model." Financial Theory and Practice (5): 6-11.

Zheng, Ming. 2003. "The Relationship between Fragility of the Banking System and Market-oriented Reforms in China." Economic Issues in China (3): 45-52.

Zhiqiang, Yi. 2012. "An Empirical Study of the Effect of Liquidity on the Performance of Commercial Banks in China." Research on Economics and Management (4):90-95. 